\title{
Phospholipid-Transporting ATPase ID
}

National Cancer Institute

\section{Source}

National Cancer Institute. Phospholipid-Transporting ATPase ID. NCI Thesaurus. Code C114665.

Phospholipid-transporting AT Pase ID (1209 aa, 137 kDa) is encoded by the human ATP8B2 gene. This protein is involved in the translocation of aminophospholipids. 